\title{
FAKTOR-FAKTOR PENGHAMBAT DAN PENUNJANG PERTUMBUHAN GEREJA
}

\author{
MORRIS P. TAKALIUANG
}

\section{PENDAHULUAN}

Prinsip yang fundamental bagi semua kehidupan adalah bahwa organisme hidup itu tumbuh. Pertumbuhan itu alamiah, sebagai pernyataan kehidupan yang spontan. Satu-satunya cara yang menghentikan pertumbuhan adalah penyakit atau kematian. Demikian pula dengan Gereja Kristus. Ron Jenson dan Jim Stevens menilai, bahwa Gereja berdenyut seiring kehidupan Kristus, maka kita berharap Gereja bertumbuh, kecuali pertumbuhannya dihambat oleh penyakit. ${ }^{1}$

Pembahasan tentang pertumbuhan Gereja dan analisis dinamikanya di balik cara bagaimana Gereja bertumbuh telah menerima daya dorong melalui pekerjaan Donald McGravan dan koleganya di Fuller Theological Seminary School of World Mission. Studi mereka telah mendorong minat dalam pertumbuhan Gereja dan menstimulir penulis dalam presentasi tulisan ini.

Bagian pertama penulis memaparkan pengertian Alkitab mengenai pertumbuhan Gereja. Bagian kedua memaparkan tentang faktor-faktor penghambat dan penunjang pertumbuhan Gereja. Sedangkan bagian ketiga menjabarkan strategi pertumbuhan Gereja. Dan ditutup dengan kesimpulan dan rekomendasi.

\section{PENGERTIAN PERTUMBUHAN GEREJA}

Suatu pengertian yang tepat dan baik tentang pertumbuhan Gereja sangat diperlukan dalam usaha memahami esensi dan eksistensi dari gerakan pertumbuhan Gereja. Esensi maksudnya adalah perlunya konsep teologis tentang pertumbuhan Gereja, dan eksistensi maksudnya adalah hadirnya gerakan pertumbuhan Gereja terkait dengan beberapa faktor yang turut mendukung maupun menghambatnya.

${ }^{1}$ Bnd. Ron Jenson dan Jim Stevens, Dinamika Pertumbuhan Gereja (Malang, Jawa Timur: Gandum Mas, 1996), 7-8. 
Pakar pertumbuhan Gereja, Peter Wagner merumuskan pertumbuhan Gereja sebagai: segala sesuatu yang mencakup soal membawa orang-orang yang tak memiliki hubungan pribadi dengan Yesus Kristus ke dalam persekutuan dengan Dia dan membawa menjadi anggota Gereja yang bertanggung jawab. ${ }^{2}$ Bagi Wagner, penginjilan dan pemuridan merupakan proses yang menghasilkan pertumbuhan kuantitatif dan kualitatif yang berjalan secara simultan dan dalam keseimbangan yang baik. Sedangkan menurut Dr. Peter Wongso, pertumbuhan Gereja adalah sebagai berikut:

Yang dimaksud dengan pertumbuhan Gereja ialah perkembangan dan perluasan Tubuh Kristus, baik dalam kualitas maupun kuantitas, dalam bentuk yang tampak. Alkitab mencacat, "Gereja adalah Tubuh Kristus" (Ef 1:23; 4:12-16; Kol 1:24). Tiap-tiap hari Tuhan menambahkan jumlah mereka dengan orang yang diselamatkan (Kis $2: 47$ ). Jelaslah ayat-ayat ini menerangkan bahwa orang yang diselamatkan (kualitas yang tak tampak), tiap-tiap hari Tuhan menambahkan jumlah mereka (kuantitas yang tampak). Ini adalah makna pertumbuhan Gereja. Ide pertumbuhan Gereja bukan berasal dari pikiran manusia, melainkan dari kehendak Allah sendiri. Tatkala Allah menciptakan manusia, Ia memberkati mereka agar mereka berkembang biak memenuhi bumi (Kej 1:27-28). Tuhan Yesus juga memerintahkan murid-murid-Nya, pergilah ke ujung bumi memberitakan Injil kepada segenap bangsa, yang percaya dan dibaptis pasti diselamatkan (Mrk 16:15-16). Maka ide pertumbuhan Gereja bukanlah berasal dari filsafat barat, melainkan kehendak Allah semula. Pertumbuhan Gereja adalah suatu masalah yang mendesak, karena Allah tidak menghendaki manusia binasa, melainkan menghendaki semua diselamatkan, percaya bahwa Tuhan Yesus adalah Juruselamat pribadi dan beroleh hidup yang kekal (Yoh 3:16; 2Ptr 3:9). ${ }^{3}$

Selanjutnya Peter Wongso dalam bukunya Tugas Gereja dan Misi Masa Kini menuliskan sebagai berikut:

Bila kita ingin Gereja bertumbuh dengan sesungguhnya, kebenaran pertumbuhan Gereja harus dijadikan suatu konsep dan pandangan yang amat kuat dalam hati setiap umat Kristen... Jika konsep dan pandangan setiap orang Kristen terhadap hal ini makin kuat, maka pertumbuhan Gereja pasti akan maju dengan pesat... jika Gereja mau mempertahankan eksistensinya, harus terus berkembang dan

\footnotetext{
${ }^{2}$ Peter Wongso, Tugas Gereja dan Misi Masa Kini (Surabaya: YAKIN, 1981),
} 80.

\footnotetext{
${ }^{3}$ Ibid., 80.
} 
bertumbuh. Gereja yang tak bertumbuh adalah Gereja yang tak mungkin mempertahankan eksistensinya. ${ }^{4}$

Sedangkan Pdt. Dr. I Wayan Mastra, berdasarkan Lukas 2:40 dan Lukas 2:52 menulis sebagai berikut:

Jika Gereja adalah Tubuh Kristus, maka dalam berbicara mengenai pertumbuhan Gereja kita tak boleh melalaikan empat unsur pertumbuhan Gereja. Pertama, Gereja harus makin bertumbuh dalam hikmat atau kebijaksanaannya secara intelektual dan akademis. Jadi, Gereja harus makin dicerdaskan. Kedua, Gereja harus bertumbuh besar dan makin kuat jasmaninya, fisiknya, materialnya atau ekonominya. Ketiga, Gereja harus makin dikasihi Allah. Jadi makin bertumbuh kehidupan rohaninya. Keempat, Gereja makin dikasihi manusia artinya makin banyak orang percaya dan melekatkan diri kepada-Nya. ${ }^{5}$

Jadi, dapat disimpulkan bahwa Gereja yang bertumbuh adalah Gereja yang diperkuat kecerdasannya, jasmaninya, kerohaniannya dan kehidupan sosialnya, sehingga ia makin disukai oleh Allah dan manusia. Dalam pertumbuhan Gereja yang utuh dan menyeluruh, maka ketiga aspek kebutuhan manusia, yaitu: kebutuhan kepala, hati dan perut harus dipenuhi agar tubuh itu dapat tumbuh seimbang dan selaras.

Pertumbuhan yang berimbang itu amat penting artinya, agar Gereja dapat menjalankan tugas dan panggilannya dengan baik. Kalau seseorang makin kuat jasmani, kebijaksanaan dan kerohaniannya, maka secara otomatis akan dihargai dalam masyarakat. Memutuskan bahwa Allah tidak menghendaki Gereja-Nya bertumbuh berarti kita telah memutuskan untuk mati. Tidak ada pilihan lain, karena makhluk hidup seharusnya bertumbuh, demikian pula Gereja harus bertumbuh karena Gereja itu hidup.

Karena itu, jika kita telah percaya kepada Imamat am orang percaya, maka setiap anggota Gereja harus mampu dalam doa, daya dan dana, melaksanakan tugas dan panggilannya. Kenyataan ini juga terdapat dalam diri rasul Paulus. Dia mengembangkan teologinya dan sekaligus penyerahan diri secara total kepada Allah dan pada saat yang bersamaan, dia berusaha sendiri dengan cara membuat dan menjual tenda untuk membiayai usaha-usaha pekabaran Injilnya. Gereja dapat berbuat demikian jika memperhatikan ketiga aspek kebutuhan anggota Gereja, yaitu: kepala, hati, dan perut dalam memikirkan pertumbuhan Gereja. Artinya, Gereja

4 I Wayan Mastra, "Kebudayaan dan Pertumbuhan Gereja" dalam Wagiyono Sumarto (ed.), Dipanggil untuk Melayani (Batu-Malang: YPPII, 1998), 314.

${ }^{5}$ Peter Wagner, Strategi Pertumbuhan Gereja (Malang: Gandum Mas, t.t), 28-29. 
harus bisa menjadi subjek dan bukan hanya objek. Gereja harus menjadi berkat dalam arti mampu memberi, karena lebih baik memberi daripada menerima (Kis 20:35).

\section{FAKTOR-FAKTOR PENGHAMBAT PERTUMBUHAN GEREJA}

Faktor penghambat pertumbuhan Gereja dapat dilihat dari lima sudut, yakni: kesalahan pemahaman teologi, kesalahan pemahaman hakikat arti misi, sosial kultural, trauma sejarah, dan agama tertentu.

\section{Faktor Kesalahan Pemahaman Teologi}

Pada tahun 1960-an, banyak orang mempersoalkan apakah Gereja seharusnya bertumbuh? Ada keragu-raguan yang datang dari beberapa orang tentang apakah Gereja dapat bermanfaat bagi masyarakat secara keseluruhan. Di dalam lingkungan tertentu untuk beberapa saat lamanya orang biasa menyampaikan bahwa kita sekarang hidup dalam suatu zaman sesudah Kristen (post christianity). Lembaga Gereja dianggap sudah ketinggalan zaman. Beberapa pengaruh dari konsep ini, masih tertinggal seperti suatu batuk kecil sesudah pilek yang berat.

Di kalangan tertentu, ada anggapan populer yang menyatakan bahwa Tuhan Yesus Kristus tidak tertarik pada perkembangan Gereja. Mereka beranggapan bahwa Yesus menganut filsafat kecil itu indah. Yesus dianggap tidak mengutamakan kesuksesan, melainkan mengutamakan kesetiaan. Misi penderitaan-Nya dinyatakan di atas kayu salib. Yesus dipandang lain oleh masyarakat pada zaman-Nya. Yesus hanya memanggil beberapa orang untuk mengikuti-Nya, Yesus lebih mengutamakan kualitas bukan kuantitas.

Orang-orang yang memandang Yesus dan pelayanan-Nya seperti ini seringkali menolak ajaran tentang perkembangan Gereja. Bagi mereka, antusiasme dan optimisme yang terdapat pada gerakan pertumbuhan Gereja tampak sebagai suatu sikap kebanggaan yang berlebih-lebihan akan keberhasilan yang tak sepadan dengan Roh Kristus. Bahkan ada yang menganggapnya serupa dengan sikap mengagung-agungkan angka dan jumlah ini, dengan mudah dapat menjadi sesuatu yang buruk dan berpusat pada diri sendiri. ${ }^{6}$

${ }^{6}$ Bnd. Peter Wagner, Penanaman Gereja untuk Tuaian yang Lebih Besar (Malang: Gandum Mas, t.t), 36-40. 
Timbul pertanyaan, benarkah Yesus memandang pelayanan dan misi-Nya seperti demikian? Setelah tiga tahun melayani murid-murid-Nya, Yesus sedang mendekati saat-saat terakhir dalam pelayanan-Nya di dalam dunia ini. Ia akan ditangkap, diadili, difitnah, diludahi, dihina, pakaian-Nya dilucuti, diejek dan disalibkan di antara dua orang penyamun. Penduduk kota Yerusalem yang dikasihi dan ditangisi-Nya justru memarahi Dia dan menghendaki penyaliban-Nya. Lebih dari itu, Ia ditinggalkan oleh muridmurid-Nya yang terdekat, orang yang disiapkan-Nya untuk melanjutkan pelayanan-Nya dikemudian hari, jika Ia pergi.

Pada saat-saat demikian, kebanyakan orang akan merasa tidak mempunyai harapan lagi, tetapi lain bagi Yesus, Dia tetap optimis. BagiNya peristiwa-peristiwa yang dilayani-Nya tak akan berakhir dalam kekalahan, tetapi dalam kemenangan. Di tengah-tengah semuanya itu Dia membuat pernyataan yang luar biasa, Injil Kerajaan ini akan diberitakan di seluruh dunia menjadi kesaksian bagi semua bangsa, sesudah itu barulah tiba kesudahannya (Mrk 24:14). Sedangkan pada saat itu pemberitaan Injil masih terbatas pada sekelompok kecil orang-orang yang terdapat di pantai Laut Tengah bagian Timur, yakni orang Yahudi di Galilea yang berbahasa Aram. Tetapi Yesus mampu memandang ke depan dan melihat pemberitaan Injil Kerajaan Allah akan terjadi kepada semua bangsa di bumi ini.

\section{Faktor Kesalahan Pemahaman Hakikat Misi}

Kurangnya pemahaman dan dangkalnya kesadaran orang-orang Kristen bahwa setiap generasi baru harus diinjili di dalam zamannya sendiri, dan juga adanya prinsip teologi bahwa Allah tidak mempunyai cucu, salah dipahami oleh Gereja, sehingga terdapat pemahaman keliru bahwa orangtua yang percaya secara sungguh-sungguh kepada Kristus dapat menyebabkan anaknya masuk ke dalam keselamatan.

Di sini dapat dipahami bahwa para orangtua yang sungguh-sungguh percaya Kristus dapat sangat mempengarui anak-anaknya mengenal Kristus, tetapi hal itu tak otomatis anak-anak tersebut langsung menerima keselamatan. Anak-anak itu perlu mengenal pribadi Juruselamat karena usaha penginjilan. Juga karena kurangnya kesadaran bahwa walaupun telah terdapat banyak pelayanan pengembalaan tetapi masih banyak domba- 
domba yang hilang dan tersesat. Dan bahwa kehendak Allah ialah dombadomba itu ditemukan kembali dan beroleh keselamatan (2Ptr 3:9). ${ }^{7}$

\section{Faktor Sosio-Kultural}

Selama 50 tahun terakhir ini, agama-agama di seluruh dunia mengalami kebangkitan. Dari pihak Gereja kenyataan ini merupakan tantangan dan hambatan bagi pertumbuhan Gereja. Apabila Gereja tidak bertumbuh, maka ketika agama lain bertumbuh, dengan sendirinya Gereja yang tak memiliki konsep yang Alkitabiah tentang pertumbuhan Gereja akan terdesak.

Pada tahun 1966, Pemerintah Indonesia mengakui ajaran Konghucu sebagai suatu agama dan mereka juga membaurkan diri dalam kegiatan masyarakat, menyusun buku-buku pelajaran dan mengajarkan ajaran etika Konghucu di sekolah-sekolah negeri dan swasta. Dewasa ini jumlah mereka telah mencapai jutaan orang di seluruh Indonesia.

Agama Budha di Asia juga ikut berkembang. Di Taiwan terdapat puluhan ribu kuil. Rakyat di sana kian percaya kepada tahyul dan mengasuh kuil Budha sehingga sudah menjadi semacam usaha baru. Banyak orang yang melayani di kuil-kuil itu mengumpulkan uang dari para pengunjung yang sembahyang di tempat tersebut dan dengan itu mengadakan pemugaran kuil-kuil Hindu.

Akhir-akhir ini agama Budha juga menerbitkan buku-buku, mendirikan sekolah-sekolah dan rumah sakit, panti asuhan yatim piatu dan lain sebagainya. Di samping itu, kerapkali mereka mengadakan ceramahceramah yang bersifat ilmiah. Candi Borobudur beberapa kali telah dipugar dan di tempat tersebut diadakan upacara besar-besaran dan umat Budha dari berbagai negara turut hadir.

Agama Islam juga mengalami kebangkitan yang luar biasa. Di samping mereka mengembangkan pendidikan dasar sampai perguruan tinggi dan rumah sakit yang sangat banyak, juga umat Islam masa kini telah mempunyai paling kurang tiga partai politik besar yang berazaskan Islam (Partai Persatuan Pembangunan, Partai Bulan Bintang, Partai Kebangkitan Bangsa), tujuan akhirnya adalah penerapan syariat Islam dalam segala aspek kehidupan masyarakat. Belum lagi berkembangnya organisasiorganisasi intelektual Islam yang sangat berpengaruh terhadap kehidupan politik dan kemasyarakatan.

7 Bnd. Stephen Neill, Colonialism and Christian Missions (London: Lutterworth, 
Selain agama-agama besar yang telah disebutkan di atas, kepercayaan lain seperti: animisme, astrologi, ilmu sihir, ilmu kebatinan, kepercayaan kepada dukun-dukun dan jimat-jimat dari agama primitif, dewasa ini telah menjadi mata kuliah dalam studi Antropologi di perguruan tinggi. Ilmu-ilmu tersebut bukan saja diilmiahkan, tetapi juga telah sangat menarik perhatian banyak sarjana yang jiwanya kosong. Di Amerika juga di Indonesia, majalah-majalah dan surat kabar-kabar besar, membuka kolom astrologia dan mempromosikannya secara besar-besaran. Penulis-penulis kolom itu kebanyakan adalah orang-orang yang bergelar dokter atau para profesor. Ini sangat menarik perhatian banyak orang yang tersesat.

\section{Faktor Trauma Sejarah}

Sejarah perkembangan dan perluasan agama Kristen atau Gereja dalam sejarah dunia, pada satu sisi merupakan suatu prestasi dan prestise tersendiri, bagi dunia misi dan zending. ${ }^{8}$ Tetapi pada sisi lain hal itu berdampak buruk pada sebagian orang, karena menimbulkan trauma sejarah yang berkepanjangan dan sulit dipulihkan. Sebagai contoh adalah sejarah Perang Salib yang sampai saat ini telah membuat orang-orang dari agama tertentu berpandangan bahwa agama Kristen adalah musuh yang harus diperangi karena telah menumpahkan darah jutaan umat agama tertentu pada zamannya. Kebencian itu sampai hari ini telah menjiwai juataan umat penganut agama tertentu terhadap orang-orang Kristen dan Gereja. ${ }^{9}$ Tentu juga ada faktor teologis lain yang menyebabkannya.

Serangan Belanda terhadap Indonesia dan penjajahan panjang terhadap Nusantara ini telah melahirkan trauma baru, di mana orang-orang non-Kristen menganggap agama Kristen identik dengan penjajah atau

${ }^{8}$ Bnd. Th. Van den End, Harta Dalam Bejana (Jakarta: BPK Gunung Mulia, 1980), 114; Bnd. Aqib Suminto, Politik Islam Hindia Belanda: Het Kantoor voor Inlandsche Zaken (Jakarta: LP3ES, 1983)

${ }^{9}$ Bnd. Anne Ruck, Sejarah Gereja Asia (Jakarta: BPK Gunung Mulia, 1997), 378-379; Bnd. Th. Van den End, Sejarah Gereja Asia (Yogyakarta: Duta Wacana, 1931), 97; Ismatu Ropi, Fragile Relation - Muslim and Christians in Modern Indonesia (Jakarta: Logos, 2000); Bnd. Olaf Schumann, "Christian-Muslim Encounter in Indonesia," dalam Yvonne Yazbeck (eds.), Christian Muslim Encounters (Gainesville: University Press of Florida, 1988), 285-287; Th. Müller-Krüger, Sejarah Geredja di Indonesia (Djakarta: Badan Penerbit Kristen, 1966), 15-20; Lih. Marwati Djoened Poesponegoro dan Nugroho Notosusanto (eds), Sejarah Nasional Indonesia. III (Jakarta: Balai Pustaka, 1990); Bnd. Sartono Kartodirdjo, Pengantar Sejarah Indonesia Baru: 1500-1900, Dari Imperium sampai Imperium (Jakarta: Gramedia, 1987), 28-65. 
agama orang barat atau kulit putih. ${ }^{10}$ Dan sekali pun alasan mereka dapat dimengerti tetapi harus diakui juga bahwa Gereja dan zending yang diutus dari barat, turut andil dalam menciptakan citra negatif tersebut. Dengan demikian mayoritas bangsa Indonesia menyimpan dendam sejarah terhadap agama Kristen, Gereja dan misi masa kini. ${ }^{11}$

Belum lagi zaman Post Modern ini, perlakukan Amerika terhadap terorisme yang begitu keras, lebih memicu dendam dan sakit hati terhadap Kekristenan, karena Amerika Serikat dianggap Negara Kristen oleh sebagian besar orang-orang non-Kristen di Indonesia. Ditambah, dukungan yang sangat kuat dari Amerika Serikat terhadap musuh bersama agamaagama tertentu, yakni Israel, turut menambah intensitas kebencian itu.

Sikap permusuhan dan anti-Kristen memuncak di Indonesia dengan pengrusakkan, pembakaran dan penutupan 800 Gereja lebih di Indonesia masa kini. Hal ini mengakibatkan ketakutan, kegelisahan dan trauma mental yang cukup berat bagi orang-orang Kristen di Indonesia. Kita melihat bahwa banyak orang Kristen yang menjadi pudar imannya lalu mundur dari iman. Inilah sebabnya beberapa orang Kristen beranggapan bahwa kita perlu kompromi, perlu mengoreksi kepercayaan kita dan bahkan tak perlu lagi menjalankan penginjilan dan misi terhadap orang-orang nonKristen tersebut. Dalam kondisi seperti ini, Gereja atau kekristenan, jelas akan merosot dan terus merosot sampai akhirnya kehilangan garam dan terangnya yakni Gereja dalam proses menuju kematian rohani.

Dalam pandangan Alkitab, Gereja yang menderita adalah Gereja yang cepat bertumbuh dan memenangkan banyak jiwa bagi Kristus. Sebab seorang Kristen yang telah lahir baru dan terus bertumbuh dalam pengenalan akan Kristus pasti akan tetap bertahan dan bertumbuh dalam hal kualitas, kuantitas dan komplesitas organisasi Tubuh Kristus. Maka benarlah yang dikatakan oleh Dr. Peter Wongso: Apabila Gereja tak bertumbuh dengan cepat, maka tatkala agama-agama lain bertumbuh, dengan sendirinya Gereja akan terdesak. ${ }^{12}$

${ }^{10}$ Bnd. Mastra, Kebudayaan dan Pertumbuhan..., 317; Onghokham, Runtuhnya Hindia Belanda (Jakarta: Gramedia, 1987), 54-63; S.C. van Randwijck, Oegstgeet: Kebijaksanaan Lembaga-Lembaga Pekabaran Injil yang Bekerjasama 1897-1942 (Jakarta: BPK Gunung Mulia, 1989),149; Lih. J. Verkuyl, Ketegangan antara Imperialisme dan Kolonialisme Barat dan Zending pada Masa Politik Kolonial Etis (Jakarta: BPK Gunung Mulia, 1990), 67-75.

${ }^{11}$ Wongso, Tugas Gereja dan ..., 63.

${ }^{12}$ Hamran Amri, Allah Sudah Pilihkan Buat Saya Hidup Baru Dalam Kristus (Jakarta: BPK Sinar Kasih, 1976), 27. 


\section{Faktor Agama}

Sandungan terbesar, terkuat dan terberat umat agama tertentu dalam memahami dan menerima kekristenan adalah karena mereka menganggap dan yakin bahwa ajaran Kristen tentang Allah Tritunggal dan tentang Yesus Kristus merupakan dosa yang tidak terampuni (dosa syirk). Menurut mereka, syirk atau mempersekutukan Tuhan Allah adalah dosa yang tak dapat diampuni. ${ }^{13}$

Sejak masa kanak-kanak penganut agama tertentu sudah diajarkan bahwa... lam yalid lam yulod... atau Allah itu tak beranak dan tidak diperanakan. ${ }^{14}$ Akibatnya, mereka tidak dapat menerima pandangan bahwa Yesus Kristus itu Anak Allah. Juga, mereka tak dapat menyebut Yesus itu Tuhan karena mereka sudah diajarkan, La ilaha illahlah atau Tiada Tuhan selain Allah. Karena inilah muncul anggapan bahwa orang-orang Kristen bersalah terhadap syirk ini karena mempercayai dan mengajarkan doktrin Allah Tritunggal.

Sementara itu di kalangan Kristen, khususnya di Indonesia ini, masalah dosa syirk ini, menjadi salah satu sebab munculnya keragu-raguan di benak mereka. Apalagi, posisi orang Kristen pada saat ia dituduh atau difitnah dan bahkan diserang oleh orang-orang penganut agama tertentu. Karena itu terhadap situasi yang demikian ini, tak jarang orang Kristen, bukan saja tak bertumbuh, tetapi malahan sedang berada dalam proses menuju kematian iman. Dan jangan lupa, pengaruh ajaran agama tertentu, telah sangat mempengaruhi perudangan-undangan di Indonesia sejak beberapa dekade yang lalu. Tetapi bagi kita yang sungguh telah percaya kepada Allah dalam Yesus Kristus dan Roh Kudus seperti yang diajarkan Alkitab, justru hal ini merupakan tantangan dan sekaligus peluang untuk menyaksikan Injil Yesus Kristus yang menyelamatkan (Rm 1:16-17).

\section{FAKTOR-FAKTOR PENUNJANG PERTUMBUHAN GEREJA}

Faktor-faktor penunjang atau penentu pertumbuhan Gereja dapat dilihat dari dua sudut, yakni faktor teologis dan antropologis. Yang

${ }^{13}$ Amri, Allah Sudah Pilihkan Buat Saya..., 14; Bnd. Yohanes D. Mansur, "To Give An Answer To Every Man: Trinitarian and Christological Views in The Apologetics of Hamran Amri of Indonesia" dalam Tesis Master of Theology (Los Angeles: Bible University, 1990), 65.

14 Bnd. Chris Marantika, Pertumbuhan Gereja Secara Alkitab dan Theologis (Jakarta: Panitia PG, 1989), 34-43. 
dimaksud dengan faktor teologis adalah keterlibatan dan peranan Allah sendiri di dalam memulai dan menumbuhkan Gereja-Nya. Sedangkan faktor antropologis bermaksud menunjukkan bahwa Allah memakai, membentuk dan memperlengkapi hamba-hamba-Nya atau manusia Tuhan yang dipilih-Nya untuk bekerja sama dengan Dia dalam rangka menumbuhkembangkan Gereja-Nya di dunia ini.

\section{$\underline{\text { Faktor Teologis }}$}

Salah satu aspek penunjang pertumbuhan Gereja adalah faktor teologis, yakni bergantung kepada Allah, dan peranan atau karya Roh Kudus dalam Gereja.

\section{Pertumbuhan Gereja Bergantung Kepada Allah}

Pertumbuhan secara kuantitatif, kualitatif dan organik dalam Gereja lokal merupakan suatu proses supranatural. Gereja adalah ciptaan Allah, Yesus Kristus adalah kepalanya. Kehidupan mengalir dari keberadaan-Nya di dalam Gereja dan pertumbuhan terjadi sebagai akibat dari kehidupan ilahi tersebut. Gereja adalah sebuah organisme yang hidup. Gereja berkembang dan bertumbuh melalui proses karya Allah, bukan perbuatan manusia. Dalam 1Korintus 3 Paulus menjelaskan tentang tanggung jawab terakhir untuk pertumbuhan Gereja: Aku menanam, Apolos menyiram, tetapi Allah yang memberi pertumbuhan (1Kor 3:6).

Rasul Paulus menguraikan bahwa setelah segala usaha manusia dilakukan, pada akhirnya pertumbuhan itu bergantung kepada Allah. Benih itu ditanam dan tanaman yang tumbuh itu disiram, dipangkas dan dipelihara, tetapi pertumbuhan adalah hasil dari proses supranatural, misterius dan ajaib yang terjadi di bawah tanah, bebas dari intervensi dan usaha manusia. Demikian juga pertumbuhan Gereja. Jikalau bukan Tuhan yang membangun Gereja, maka sia-sialah usaha manusia yang mengorganisir, merencanakan dan membiayainya (bnd. Mzm 127:1). Sebelum kita mengakui adanya unsur supranatural dalam proses pertumbuhan Gereja dan menempatkan usaha manusia pada proporsinya, maka tidak ada nilai benar dan kekal yang dapat dicapai dari diri kita sendiri; kita tak dapat membuat Gereja bertumbuh (Yoh 15:5). ${ }^{15}$

\footnotetext{
${ }^{15}$ Bnd. Billy Graham, Roh Kudus (Bandung: Lembaga Literatur Baptis, 1985), 71.
} 
Kita mungkin berpikir sejenak dan kemudian memuji keberhasilan kita karena sifat yang baik, karunia rohani yang hebat, adanya sumbersumber dana atau karena kepempinan gembala yang kuat. Tetapi tanpa mengecilkan faktor di mana Allah memakai keterlibatan manusia, pertumbuhan Gereja tetap tergantung pada Allah dan di dalamnya Allah memakai manusia yang bergantung kepada-Nya (Yoh 15:1-8).

Gereja-gereja yang dibangun berdasarkan talenta berkhotbah yang hebat atau kemampuan berorganisasi seseorang, harus menolak godaan untuk memuji manusia sebagai penyebab pertumbuhan sebuah Gereja. Paling tepat, jika kita berkata, kita adalah orang-orang yang menanam dan orang-orang yang menyiram tetapi Allah yang menghidupkan dan menumbuhkan Gereja dan hanya Dia saja yang layak menerima pujian.

Timbul pertanyaan, bagaimana hal tersebut di atas berhubungan dengan doa? Jawabannya adalah: jika kita percaya bahwa pertumbuhan Gereja berasal dari Allah dan kerenanya bersifat supranatural dan jika kita sadar bahwa kita bergantung kepada Allah dalam proses pertumbuhan Gereja, maka doa juga di dalam tuntunan Allah (Roh Kudus) akan menempati urutan teratas dari susunan daftar prioritas kita. Jika Allah yang menyebabkan pertumbuhan, maka kita harus berhubungan dengan Dia, jika tidak, maka kita berusaha dengan sia-sia, menjalankan roda pelayanan kita tanpa hasil rohani yang diharapkan.

Perubahan dan pertumbuhan roahni yang sejati akan terjadi hanya karena jawaban doa, sementara kita terus belajar untuk bergantung kepadaNya Fokus harus dialihkan dari diri kita sendiri kepada Allah. Dan jika kemampuan kita berasal dari Allah dan bukan dari diri kita sendiri dalam segala hal, maka pastilah fokus kita harus berpusat pada Allah sebagai sumber segala kekuatan kita. Supaya kita menjadi semakin yakin bahwa sumber pertumbuhan Gereja adalah dari Allah saja dan bahwa usaha manusia sia-sia adanya tanpa berkat-Nya, maka seharusnya kita memahami petingnya peranan Roh Kudus dalam Gereja.

\section{Pertumbuhan Gereja Bergantung Kepada Peranan Roh Kudus}

Gereja lahir, bertumbuh dan tetap eksis karena pekerjaan Roh Kudus. Roh Kudus-lah yang membawa orang-orang ke dalam Gereja. Perubahan-perubahan yang terjadi di dalam hidup seseorang sehingga mengalami kelahiran baru, makin berakar dan bertumbuh di dalam Kristus 
merupakan karya Roh Kudus. ${ }^{16}$ Karya tersebut dapat diamati dalam proses di bawah ini.

\section{$\underline{\text { Roh Kudus Menginsafkan }}$}

Roh Kudus mengisafkan manusia akan dosa-dosanya ketika Ia mendirikan Gereja (Yoh 16:8-11). Dalam bagian lain Yesus menegaskan bahwa, tak ada seorang pun yang dapat datang kepada-Ku jikalau ia tak ditarik oleh Bapa yang mengutus Aku (Yoh 6:44). Kesadaran akan pendekatan ilahi membuat kita sadar bahwa Allah memulai dengan caraNya yang misterius, menarik, melembutkan dan menciptakan kesadaran akan kebutuhan dalam hati seseorang akan pentingnya keselamatan atau lahir baru.

Kita harus sadar bahwa Roh Kudus, dengan cara yang kadangkadang tak kita mengerti dan di luar kemampuan kita, bekerja di dalam hati seseorang mendatangkan keselamatan. Kita berpikir bahwa latihan, kemampuan dan pengetahuan kita sebagai penyebab kesadaran seseorang. Roh Kudus menggunakan sumber daya manusia dalam pekerjaan-Nya tetapi tanggung jawab untuk menyadarkan seseorang adalah karya-Nya sendiri.

\section{$\underline{\text { Roh Kudus Mengerjakan Pertobatan }}$}

Roh Kudus mengerjakan pertobatan yang sejati di dalam hati seseorang. Pertobatan adalah buah dari kesadaran yang membawa kepada keputusan, di mana caranya sulit untuk dipahami. Roh Kudus menarik kita dan menciptakan di dalam kita kesadaran akan kebutuhan kita yang paling dalam. Ia kemudian memberikan kemampuan kepada kita untuk percaya kepada berita Injil dan menempatkan iman kita kepada-Nya. Ia menyebabkan perubahan itu terjadi. Titus 3:5 menjelaskan proses tersebut: Oleh pemandian kelahiran kembali dan oleh pembaharuan yang dikerjakan oleh Roh Kudus. Hal yang perlu diigat bahwa sebagai manusia, kita tidak memiliki peran apapun dalam kelahiran baru atau pembaharuan seseorang, selain hanya menyampaikan berita Injil. Tentang hal ini, Billy Graham menjelaskan sebagai berikut:

Pembaharuan itu bukanlah pekerjaan penginjil, itu adalah pekerjaan Roh Allah. Syarat yang tak dapat dipisahkan dari kelahiran baru

\footnotetext{
${ }^{16}$ Bnd. Graham, Roh Kudus..., 81.
} 
adalah pertobatan dan iman, tetapi pertobatan dan iman itu sendiri tak menyelamatkan. Iman yang sejati itu adalah pemberian Allah kepada seseorang seperti yang telah saya katakan bahkan menolong kita untuk bertobat. ${ }^{17}$

\section{$\underline{\text { Roh Kudus Menciptakan Pengakuan }}$}

Hal Penting lainnya dalam karya Roh Kudus selain menginsafkan dan menobatkan seseorang adalah adanya pengakuan bahwa Yesus adalah Tuhan (Rm 10:9-10). Dalam 1Korintus 12:3, dijelaskan: Tak ada seorang pun yang dapat mengaku Yesus adalah Tuhan selain oleh Roh Kudus. Roh Kudus saja yang menyebabkan seseorang bertobat kemudian membuatnya mengakui di dalam hati dan dengan kata-kata di dalam mulutnya, bahwa Yesus adalah Tuhannya.

\section{Roh Kudus Memperlengkapi Gereja}

Roh Kudus memperlengkapi Gereja di samping membawa orangorang ke dalam Gereja. Roh Kudus juga mengarahkan pertumbuhan individu-individu tersebut ke tingkat yang lebih dalam dan tinggi di dalam Tuhan Kristus Yesus.

Perlu disadari bahwa kita tak dapat menyebabkan pertumbuhan Gereja sama seperti halnya pertobatan. Surat Galatia 5:22 melukiskan sembilan kualitas sifat atau karakter dan tingkah laku Kristus dalam diri seorang Kristen sebagai buah pertumbuhan rohani, yang disebut Paulus sebagai buah Roh. Buah Roh di sini bukan berasal dari manusia yang mengalaminya tetapi dari Roh yang tinggal di dalamnya. Ini terjadi pada individu-individu yang berada dan tinggal di dalam Tubuh Kristus.

Efesus 3:16 berkata tentang aktifitas Roh ini yang terjadi di dalam batin manusia. Jika Roh Kudus tinggal dalam batin seseorang, maka ia juga bekerja di dalam orang tersebut. Ia menggerakkan, mengubah, menuntun dan menggembalakannya menjadi seperti Kristus dalam tiga cara utama.

Pertama, melalui Firman Tuhan. Roh Kudus memperlengkapi Gereja melalui Firman Allah. Ibrani 4:12 melukiskan bahwa Firman Allah itu hidup, kuat dan tajam. Selanjutnya dalam Yohanes 16:13 ditulis bahwa Roh akan memimpin kita ke dalam seluruh kebenaran yaitu kebenaran tentang Tuhan Yesus Kristus. Konteks dari ayat ini adalah percakapan di

${ }^{17}$ Stephen Tong, Roh Kudus, Suara Hati Nurani dan Setan (Jakarta: Lembaga Reformed Injili Jakarta, 1997), 115-116. 
mana Yesus sedang berhubungan dengan murid-murid-Nya berkaitan dengan hubungan-Nya dengan Allah, Kerajaan Surga dan mereka sendiri. Kata Yesus kepada mereka bahwa salah satu pelayanan Roh Kudus atau Penghibur adalah mencelikkan mata rohani mereka yang buta dan memimpin mereka kepada pengertian yang mendalam tentang Kristus, Anak Allah yang hidup. Roh Kudus yang hidup menggunakan Firman Allah yang hidup, memberinya kuasa, dan dengan cara ajaib atau misterius, supranatural, memakainya untuk mengubah seseorang di dalam hatinya dan menumbuhkan kualitas rohaninya.

Dalam 1Tesalonika 2:13 Paulus berbicara tentang Firman yang bekerja dalam hidup mereka yang percaya. Hubungan yang erat dan harmonis antara Roh yang bekerja melalui Firman Allah ditegaskan lagi oleh Stephen Tong sebagai berikut:

Dan semua yang disebut sebagai suara Roh Kudus harus sesuai dan harmonis dengan prinsip-prinsip yang ada di seluruh Kitab Suci. Tidak ada konflik dengan Firman. Jangan membedakan dan memisahkan Roh Kudus dari Firman. Roh Kudus adalah kebenaran dan Kitab Suci adalah kebenaran yang diwahyukan oleh Roh Kudus, karena Roh Kudus adalah roh kebenaran, maka Roh Kudus yang mewahyukan kebenaran, mencerahkan orang akan kebenaran dan memimpin Gereja kembali, masuk ke dalam pengertian dan kenikmatan kebenaran. Roh Kudus dan kebenaran tak boleh dipisahkan. ${ }^{18}$

Kedua, melalui manusia-manusia Tuhan. Di samping menggunakan Firman Allah, Roh Kudus juga menggunakan orang-orang dalam menyatakan dan menyingkap makna Firman Allah. Menurut Efesus 4:12, Allah telah memberikan orang-orang yang mempunyai karunia kepada Gereja untuk memperlengkapi orang-orang kudus bagi pekerjaan pelayanan. Seringkali kita melihat laki-laki dan perempuan yang sebelumnya mati secara rohani, datang ke dalam keluarga Allah dan mulai berkembang sementara mereka belajar dari pelayanan Firman yang dinyatakan oleh seorang pengkhotbah, guru, gembala-gembala dan penginjil yang memiliki karunia.

Seringkali terjadi seorang hamba Tuhan memerlukan waktu berjamjam untuk menyiapkan sebuah khotbah, tetapi sesudah menyampaikannya ia mendapati bahwa orang-orang diberkati dan mengalami pertumbuhan iman dan pengertiannya akan rencana Allah bagi dirinya dan dunia. Dalam

${ }^{18}$ Bnd. David Iman Santoso, "Pertumbuhan Gereja dan Peranan Roh Kudus" dalam Tantangan Gereja di Indonesia (Surabaya: YAKIN, 1990). 
hal ini Roh Kudus telah bekerja, menyatakan kesalahan, memperbaiki kelakuan dan mendidik orang dalam kebenaran (2Tim 3:16-17).

Jadi, Roh Kudus menggunakan hamba Tuhan untuk menjelaskan arti Firman Tuhan. Tetapi Roh Kudus sendiri akan bekerja pada tingkat yang lebih mendalam, menggunakan Firman yang membawa kepada perubahan dan pertumbuhan rohani.

Ketiga, melalui karunia-karunia Roh Kudus. Cara kerja Roh Kudus yang ketiga dalam memperlengkapi Gereja adalah dengan mengaruniakan karunia-karunia rohani kepada orang-orang percaya secara pribadi. Allah memberikan kepada setiap orang sedikitnya satu karunia rohani untuk mengisi peranan khusus dalam Gereja. Setiap karunia menyumbangkan sesuatu kepada Tubuh Kristus. Persoalan dan sampai pada perpecahan dalam Gereja terjadi karena masing-masing orang Kristen tak melayani sesuai dengan jenis pelayanan yang diberikan oleh Roh Kudus kepadanya (tak sesuai dengan karunia Roh yang ada padanya).

Kita masing-masing memiliki keterbatasan tetapi Allah telah memberikan kemampuan atau karunia-karunia kepada yang lain untuk mengisi dan mengimbangi keterbatasan dan kekurangan-kekurangan kita. Tidak ada satu manusia pun yang dapat menjadi manusia super. Tiap-tiap anggota mempunyai kemampuan atau karunia unik. Dan kita harus menjalankan karunia-karunia itu, bukan meremehkan atau pun memamerkannya. Dengan perkataan lain setiap orang Kristen, mesti menemukan sebuah tempat pelayanan yang diberikan oleh Roh Kudus kepadanya untuk mengembangkan karunia rohani yang dimilikinya. Sebab dengan cara demikian pertumbuhan Gereja yang diharapkan dapat tercapai. ${ }^{19}$

\section{Faktor Antropologis}

Faktor kedua terjadinya pertumbuhan Gereja adalah aspek antropologis yang meliputi enam pernan penting, yakni: doa, iman, kepemimpinan yang memberdayakan, struktur pelayanan yang efektif, ibadah yang membangkitkan inspirasi, serta kelompok kecil yang menjawab kebutuhan anggota Gereja.

${ }^{19}$ E.M. Bounds, Power Through Prayer (Grand Rapids: Baker Book House, 1972); Bnd. Peter C. Wagner, Your Church Can Grow (Glendale, California: Regal Books, 1976). 


\section{Peranan Doa}

Pertumbuhan Gereja secara kualitatif, kuantitatif dan organis, akan terjadi jika kita sadar bahwa implikasi dari pekerjaan dan pelayanan Roh Kudus adalah dorongan, komitmen dan kegiatan doa yang lebih serius dengan yang kita lakukan sebelumnya. Allah mengasihi dan memelihara Gereja-Nya. Ia selalu siap memberkati umat-Nya. Tetapi terkadang Allah menunggu kita agar meminta daripada-Nya (Yoh 14:13-14, 15:7-8). Tantangan Firman Tuhan benar secara teologis tetapi jarang dan kurang dipraktikkan. Kita sering berpendirian dan berpikir bahwa kita dapat menjalankan kehidupan Gereja (kekristenan kita) dengan baik, dengan menggunakan sumber daya kita sendiri, tanpa mempedulikan kekuatan ilahi. Kita kurang memiliki pengertian perlunya bergantung kepada Allah. Kita berpikir bahwa kita tahu bagaimana menyusun program yang kreatif sehingga ada kegiatan untuk setiap kelompok umur dan profesi. Kita tahu bagaimana menyampaikan pikiran-pikiran teologis dengan cara menarik. Kita tahu bagaimana cara membangun fasilitas yang bagus untuk mewadahi program-program kita. Mungkin juga kita tahu, bagaimana menerapkan struktur badan usaha ke dalam Gereja sehingga organisasi kita menjadi hebat, kita tahu melakukan hal-hal tersebut dan kita berpikir, semua itu dapat dilakukan tanpa keterlibatan Allah. Kurangnya pengertian terhadap kebutuhan akan Allah menghilangkan pengertian kita akan perlunya berdoa. Doa pribadi dan bersama tidak antusias, mencerminkan kurangnya pengertian kita tentang proses supranatural yang bekerja dalam pertumbuhan Gereja.

Kita sering berbicara tentang doa secara abstrak, lalu berdoa tidak lagi menjadi prioritas kita. Kelesuan terhadap doa merupakan akibat dari kecenderungan kita untuk mengukur hasil-hasil dengan cara-cara yang berbeda dari sifat-sifat Allah. Sarana pengukur kita menunjuk kepada jumlah anggota, jumlah rupiah atau fasilitas-fasilitas. Meskipun Allah juga peduli terhadap aspek-aspek tersebut, namun Allah lebih melihat pada kondisi hati manusia. Ia peduli terhadap dosa yang tak diakui; apakah kita mengasihi Dia dan mengasihi satu terhadap yang lain? Apakah kita peduli terhadap mereka yang terhilang?

Rasul Paulus memberi contoh-contoh doa bagi kita. Ia secara terusmenerus berdoa agar jemaat-Nya mengembangkan kualitas-kaulitas rohani yang merupakan hal yang paling penting. Ia berdoa bagi kasih yang dalam di antara orang percaya, bagi pengertian yang makin jelas tentang siapakah Yesus, dan bagi peningkatan kesabaran dalam penderitaan dan penganiayaan (Ef 3:14-21). Jika kita mulai melihat bahwa hal-hal itu tak 
akan terjadi kecuali melalui jawaban doa, maka doa akan menjadi lebih daripada sekedar program pilihan atau tambahan saja. Sebaliknya doa akan menjadi kekuatan yang mendorong pertumbuhan Gereja. ${ }^{20}$

\section{Peranan Iman}

Karya Roh Kudus dalam pertumbuhan Gereja mempunyai implikasi bagi iman kita. Persoalan kita, seringkali terlalu banyak di antara kita masuk dan terjual dalam sebuah pelayanan pemeliharaan (status qua). Terdapat suatu kekurangan dan ketidakpercayaan bahwa Allah akan melakukan mujizat. Kita telah menjadi satu generasi yang ragu-ragu dan mungkin takut. Kita sering menganggap Allah tidak dapat melakukan halhal yang besar dan tak terpahami (Yer 33:3). Atau mungkin kita juga masih percaya tetapi hanya dalam tingkatan ajaran atau doktrin saja di dalam pemikiran kita. Salah satu sebabnya adalah karena kita tak memiliki iman terhadap perkara-perkara yang besar dari Allah. Kita akan percaya kepada Allah jika kita merasa terpaksa. Kita cenderung melihat pada setiap altematif manusia dalam penyelesaian suatu masalah, sebelum akhimya kita berpaling kepada Allah. Untuk mengajar murid-murid tentang iman, berkali-kali Yesus membawa mereka ke dalam situasi yang tak berpengharapan dari sudut pandang manusia (badai di laut, 5.000 orang yang harus diberikan makan, dan lain sebagainya). Yesus sedang melatih mereka untuk beriman dan berpaling kepada-Nya dengan sebuah sikap ketergantugan dan berpengharapan di dalam Dia saja. Kita akan belajar berpaling kepada-Nya, hanya jika kita telah mulai melihat kegagalan usaha manusiawi untuk menghasilkan perkara-perkara rohani di luar Dia.

Kurangnya iman yang membawa ketergantungan kepada Allah dapat ditelusuri pada pengertian tentang siapa yang bertanggung jawab terhadap pertumbuhan Gereja. Jansen dan Jim Stevens menegaskan:

Jika kita percaya bahwa pertumbuhan adalah karya manusia, maka kita akan berpaling kepada manusia untuk memperoleh sumbersumber daya; perhatian kita akan berada pada rencana-rencana dan strategi-strategi kita. Kita akan cenderung menggunakan cara penyeleksian manusiawi terhadap masalah-masalah yang tak terselesaikan. Tetapi hasil dari proses buatan manusia adalah sebuah produk karya manusia. Jika Gereja harus bertumbuh, Gereja harus bergantung dengan kendali manusia. Jika Gereja harus bertumbuh, Gereja harus bergantung kepada Allah, Gereja juga akan

\footnotetext{
${ }^{20}$ Benson dan Jim Stevens, Dinamika Pertumbuhan..., 33.
} 
berpengharapan. Seluruh proses akan menjadi sebuah pengalaman besar seperti yang seharusnya. Pengalaman untuk melihat Allah yang hidup terus-menerus melakukan perkara-perkara yang tak dapat dijelaskan dengan bahasa manusia. Jika kita tahu bahwa hanya Allah yang dapat melakukan hal-hal tersebut terjadi, maka kita akan meminta kepada-Nya perkara-perkara yang mustahil dan percaya bahwa Ia akan melakukannya. ${ }^{21}$

Karena itu, orang-orang Kristen perlu belajar bagaimana berdoa dan melangkah dengan iman dalam setiap peristiwa. Peristiwa-peristiwa iman menantang umat Allah untuk percaya bahwa Ia akan memberikan sesuatu di luar jangkauan mereka. Gereja perlu dimobilisir agar melalui iman mendoakan perkara-perkara besar. Mulai dengan doa bersama untuk situasi yang tampaknya tak berpengharapan. Misalnya sang pecandu alkohol yang perlu dilepaskan, sebuah keluarga yang tampaknya harus bercerai atau orang-orang yang telah tersesat pada jalan Setan dan sebagainya.

Banyak Gereja mengalami kemunduran rohani dan moral. Mereka memiliki mentalitas yang lelah. Tetapi keadaan demikian dapat berubah jika kelompok-kelompok Kristen berdoa bagi hal-hal yang tak mungkin. Allah pasti menyukai doa-doa semacam itu dan Ia akan menanggapinya. Iman melibatkan resiko dan usaha tanpa takut akan kegagalan. Tetap beriman walaupun dalam situasi yang tak menyenangkan. Ini berarti bahwa orang Kristen harus belajar nyerempet-nyerempet bahaya. Ini juga berarti orang-orang Kristen belajar meremehkan kesulitan-kesulitan. Tentang hal ini, seorang pakar pertumbuhan Gereja menulis sebagai berikut:

Sejarah berhubungan dengan pertumbuhan Gereja, salah satu hasil dari studi kami menunjukkan bahwa kenyataan yang penting, bukanlah bagaimana cara kerohanian diekspresikan, melainkan kenyataan bahwa iman dihayati dan diamalkan berdasarkan komitmen yang berapi-api dan antusiasme. Tingkat kehausan rohani, jelas merupakan titik yang memisahkan Gereja yang bertumbuh dengan yang tidak. ${ }^{22}$

${ }^{21}$ Christian A. Schwarz, Pertumbuhan Gereja yang Alamiah (Jakarta: Metanoia, 1998), 14.

22 Bnd. Schwarz, Pertumbuhan Gereja yang..., 12; David A. Womack, The Pyramid Principle (Minneapolis: Bethany Fellowship, 1977), 79; Michale Tucker, The Church Change or Decay (Wheaton, Illinois: Tyndale, 1978); John Alexander, Practical Criticism: Giving and Receiving It (Downers Grove, Illinois: InterVarsity Press, 1976); Dan Benson, The Total Man (Wheaton, Illinois: Tyndale, 1977); Richard Havenson, How I Changed My Thinking About the Church (Grand Rapids: Zondervan, 1972). 


\section{Peranan Kepemimpinan yang Memberdayakan}

Hasil studi dan penelitian para pakar pertumbuhan Gereja membuktikan bahwa para pemimpin Gereja yang bertumbuh tidaklah berusaha membangun kekuasan mereka untuk menjadi sangat dominan. Justru sebaliknya mereka menganggap salah satu tugas yang terpenting adalah menolong orang-orang Kristen mengembangkan tingkat kemampuannya, menurut yang telah Allah berikan kepada mereka. Para pemimpin di sini melayani untuk memperlengkapi, mendukung, memotivasi dan menjadi mentor bagi individu-individu untuk menjadi seperti yang Allah kehendaki atas mereka. Beginilah sifat daripada kepemimpinan Kristus yang berjiwa memuridkan segala bangsa bagi perluasan kerajaan-Nya di bumi ini. ${ }^{23}$

\section{Peranan Struktur Pelayanan yang Efektif}

Kriteria paling penting untuk bentuk dan struktur di dalam Gereja yang bertumbuh adalah apakah Gereja-gereja tersebut memenuhi tujuannya, apakah Gereja tersebut jalan di tempat atau sedang mundur dan akhimya merosot, yang ujung-ujungnya menjadi Gereja yang mati? Struktur Gereja sendiri tak pernah dan tidak boleh menjadi tujuan, tetapi selalu hanya merupakan sarana untuk mencapai suatu tujuan. Disarankan oleh para pakar supaya apa pun yang tak memenuhi persyaratan-persyaratan ini seperti, struktur kepemimpinan, merendahkan martabat, waktu ibadah yang tak tepat atau program yang tak menjangkau khalayak secara efektif lebih baik diubah dan dinonaktifkan. Melalui proses pembaharuan ini, kebiasaan yang hanya bersifat tradisi dapat dipertahankan sejauh masih efektif. ${ }^{24}$

\section{Peranan Ibadah yang Membangkitkan Inspirasi}

Ibadah yang dimaksud dengan membangkitkan inspirasi adalah kegiatan menyembah Allah, bersekutu dengan Dia, berdoa kepada-Nya, memuji dan menyanyi bagi Allah, mengaku dihadapan-Nya dan memberi tanggapan kepada-Nya, sebagaimana layaknya Ia patut ditinggikan dan dimuliakan seperti yang dinyatakan dalam firman-Nya. Dalam ibadah ini pertanyaan yang patut disampaikan adalah apakah ibadah merupakan pengalaman yang membangkitkan inspirasi bagi mereka yang

\footnotetext{
${ }^{23}$ Schwarz, Ibid..., 15-16.

${ }^{24}$ Schwarz, Pertumbuhan Gereja yang..., 16-17.
} 
menghadirinya? Jika ya maka ibadah itu akan dihadiri dan dinikmati, jika tidak maka ibadah itu kurang diminati.

Bidang ini secara jelas memisahkan Gereja yang bertumbuh dengan Gereja yang tidak bertumbuh. Dari sekian banyak kelompok Kristen, terdapat pemikiran yang berbeda-beda tentang fungsi dan manfaat ibadah. Di antaranya ada yang biasa beribadah hanya sekedar memenuhi tuntutan agamanya, datang ke Gereja hanya demi berbuat baik bagi Allah atau bagi gembalanya atau orang lain. Beberapa orang di antara mereka percaya bahwa kesetiaan dalam beribadah seperti itu diberkati oleh Allah. Sedangkan bagi yang lain ibadah itu benar-benar sangat menggairahkan dan membangkitkan inspirasi dan semangat. Dalam posisi dan pandangan yang mana kita berada, merupakan petunjuk dan pertanda yang jelas tentang keadaan Gereja kita. Ibadah yang benar dan mendatangkan kualitas pembaharuan, itulah salah satu sebab bagi pertumbuhan Gereja baik kualitas maupun kuantitas dan organis. ${ }^{25}$

\section{Peranan Kelompok Kecil yang Menjawab Kebutuhan Anggota}

Penelitian para pakar telah membuktikan bahwa Gereja yang bertumbuh lezimnya adalah Gereja yang mengembangkan hadirnya sistem kelompok kecil, dimana setiap orang Kristen dapat berkomunikasi dengan intim, mendapat pertolongan sehari-hari dan dukungan pertumbuhan rohani yang tetap dalam kelompok ini. Isi Alkitab di dalam kelompok ini, diterapkan dalam kehidupan sehari-hari. Kelompok kecil seperti ini, bukanlah suatu pilihan hati atau kesenangan yang dilakukan bila ada waktu, tetapi ini merupakan pokok kehidupan yang utama dari Gereja Tuhan yang bertumbuh. Dalam buku Bukan Sekadar Jumlah, Dr. Yonggi Cho menjelaskan pentingnya pelayanan di dalam Kelompok Sel.

Terdapat banyak orang di tengah-tengah masyarakat kita, yang telah menjadi anggota dari suatu Gereja, akan tetapi sekarang tak lagi menghadiri kebaktian dimana pun juga. Oleh karena sesuatu alasan maka menggabungkan diri dengan jumlah guguran orang-orang Kristen yang kita saksikan tersebar di seluruh dunia. Sebagian besar dari guguran orang-orang Kristen itu, menurut pandangan saya, mempunyai alasan yang sama. Mereka masih tetap percaya kepada Yesus Kristus. Mereka masih tetap menganggap diri sebagai orang Kristen, akan tetapi mereka telah dikecewakan oleh pihak Gereja.

25 Yonggi Cho, Bukan Sekedar Jumlah (Jakarta: Yayasan Pekabaran Injil Immanuel, 1985), 71. 
Beberapa di antaranya bahkan ada yang telah melibatkan diri dalam perpecahan Gereja. Sebagian lagi di antaranya ada yang merasa kecewa terhadap pendeta atau gembala sidang mereka, atau terhadap kepimpinan Gereja mereka. Ada lagi yang mungkin telah jatuh ke dalam lembah dosa dan sudah meras amalu untuk kembali ke Gereja, sebagian lagi ada yang mungkin merasa malu untuk kembali ke Gereja, sebagian lagi ada yang mungkin merasa diabaikan oleh gembala sidang, yang tidak pernah datang berkunjung menengok mereka entah apa pun alasannya, kita temukan masih ada kelompok besar orang-orang yang perlu untuk kita capai dan sentuh mereka demi kepentingan Tuhan kita, agar supaya mereka boleh disembuhkan dan dapat dikembalikan lagi ke dalam himpunan kelompok domba-domba. ${ }^{26}$

Jadi, cukup penting kelompok kecil itu diadakan dalam rangka memulihkan kembali orang-orang Kristen dari persoalan mereka dan kemudian orang-orang Kristen ini perlu berkembang atau bertumbuh di dalam Tuhan. Karena Allah menginginkan setiap orang percaya mengembangkan karakter Kristus dalam hidupnya. Dalam hal ini diperlukan tekat dan komitmen dari setiap orang Kristen.

Dengan pertolongan Tuhan kita dapat menjadi apa saja sesuai dengan tekad kita, karena kesehatan rohani tergantung pada latihan rohani yaitu mendisiplinkan diri untuk melakukannya hingga hal-hal tersebut menjadi kebiasaan (1Kor 9:27).

Orang-orang percaya akan bertumbuh lebih cepat jika mereka menyediakan jalan untuk bertumbuh dan dalam kaitan ini orang Kristen membutuhkan hubungan dengan sesama untuk dapat bertumbuh, karena kita bertumbuh dalam konteks persekutuan. ${ }^{27}$

Kita tak dapat berbicara tentang karakter tanpa berbicara tentang kebiasaan, karakter seperti Kristus merupakan tujuan akhir dari semua pendidikan dan disiplin Kristen, karakter ini dibentuk dalam keadaankeadaan di lingkungan persekutuan, pergaulan dan kehidupan. ${ }^{28}$

26 Bnd. John W. Alexander, Practical Criticism: Giving and Receiving It (Downers Grove, Illinois: InterVarsity, 1976); Gene A. Getz, A Building Up One Another (Wheaton, Illinois: Victor Boks, 1976); Ronald Jenson, How to Succeed the Biblical Way (Wheaton, Illinois: Tyndale, 1981), 87-94; Bnd. Lawrence O. Richard, A New Face for the Church (Grand Rapids: Zondervan, 1970)

${ }^{27}$ Bnd. Rick Warren, Pertumbuhan Gereja Masa Kini. Terj. (Malang: Gandum Mas, 1999), 327, 333, 339.

${ }^{28}$ Ted W. Engstrom, The Making of a Christian Leader (Grand Rapids: Zodervan, 1976), 14; Lih. Gene A. Getz, Sharpening the Focus of the Church (Chicago: Moody 


\section{Faktor Strategi}

Gereja dapat bertumbuh jika penginjilan yang dilakukan didukung oleh strategi dipimpin oleh Roh Kudus. Dalam kitab Kisah Para Rasul ditunjukkan bahwa Roh Kudus adalah ahli strategi Agung. Roh Kudus adalah pengawas tertinggi dari kampanye misi yang besar. Roh Kudus memberi kuasa dan mengambil prakarsa (Kis I:8, 13:1-4), membimbing dan mengarahkan (Kis 8:29, 16:6-10).

Langkah utama dalam kerangka strategi adalah penetapan tujuan scperti yang dikemukakan oleh Tuhan. Dalam Kisah Para Rasul 1:8, di mana Tuhan Yesus memberi tugas kepada munid-murid-Nya: Tetapi kamu akan menerimna kuasa, kalau Roh Kudus turun ke atas kamu, dan kamu akan menjadi saksi-Ku di Yerusalem dan di seluruh Yudea dan Samaria dan sampai ke ujung bumi. Bagian bumi yang paling jauh menjadi tujuan dan penginjilan yang sepenuhnya dipimpin olel Roh Kudus.

Beberapa pengamatan berikut menunjukkan strategi yang telah mendorong penginjilan dan pertumbuhan Gereja, yakni: tempat yang dipilih oleh Tuhan, waktu yang ditetapkan Tuhan, pembentukan hamba-hamba Tuhan, dan visi universal dari Tuhan.

\section{Tempat yang Dipilih Tuhan}

Kunjungan Allah terjadi di Yerusalem, pusat ibadah dan ajaran Yahudi zaman itu. Roh Kudus turun pada hari Pentakosta dan melahirkan umat Allah yang baru, sebuah lembaga baru-Gereja-telah tercipta. Jadi, Yerusalem telah menjadi pusat manifestasi kuasa Allah. Allah memilih sebuah tempat untuk menyatakan kuasa-Nya. Prinsip rohani yang dapat diambil dalam peristiwa ini adalah Allah dalam strategi-Nya memilih tempat yang ditunjukkan-Nya untuk melakukan sesuatu demi kelahiran dan pertumbuhan Gereja-Nya.

\section{Waktu yang Ditetapkan Tuhan}

Intervensi Allah terjadi pada waktu yang tepat (waktu yang ditetapkan Tuhan). Saat itu ribuan orang Yahudi, orang-orang yang takut akan Allah, dan orang-orang beragama lain memenuhi kota Yerusalem

Press, 1976); R. Alec Mackenzie, The Time Trap (New York: McGraw-Hill, 1975); Lyle E. Schaller, Parish Planning (Nashville: Abingdon, 1975). 
untuk perayaan-perayaan keagamaan. Pada saat itu Allah mengirim Roh Kudus, banyak orang bertobat dan menjadi anggota Gereja mula-mula.

Pada peristiwa Pentakosta tersebut, muncul pemberita-pemberita Injil yang utama seperti: Barnabas, Stefanus, Filipus dan yang lain (Kis 6:5). Juga ketika terjadi penganiayaan, memaksa orang-orang percaya meninggalkan Yerusalem, dan pergi, membawa berita Injil ke negeri-negeri dimana mereka tinggal (Kis 8:4, 11:19-22).

\section{Pembentukan Hamba-Hamba Tuhan}

Tuhan memberikan waktu persiapan bagi orang-orang percaya yang baru mengalami kelahiran baru untuk mengembangkan hubungan spiritual dan kemasyarakatan yang baru, serta untuk dibentuk menjadi murid-murid Kristus. Mereka diberi pengajaran untuk menjadi saksi demi menjaga kesatuan, kesehatan iman, serta diajar untuk melaksanakan fungsi sebagai anggota-anggota yang bertanggung jawab dalam bersaksi, berdoa dan hidup dalam masyarakat (Kis 2:42-46, 4:23-41, 5:42; 6:1-7, 8:4: 11:19-21, 12:5).

\section{Visi Universal dari Tuhan}

Paulus mempunyai visi misi universal yang jelas. Setelah didesak ke luar dari Yerusalem, dia mengubah perhatiannya pada Asia Kecil, bekerja keras pertama di Tarsus dan Antiokhia (Kis 11:25-30, 13:1-3), kemudian ke Asia Kecil bagian barat, di mana Efesus sebagai pusatnya (Kis 19:1-20:38). Dari situ Paulus melihat ke arah barat dengan Roma sebagai pusat, dan Spanyol sebagai bagian yang paling jauh (Kis 19:21, 23:11, 28:14-31; Rm 1:9-15, 15:24-28). Inilah orang dengan visi yang universal.

Pentingnya dan efektifnya sebuah strategi, nampak dari hasil-hasil pelayanan seperti yang disebutkan dalam Kisah Para rasul.

- Kamu telah memenuhi Yerusalem dengan ajaranmu (Kis 5:28)

- Dan Firman Allah makin tersebar, dan jumlah murid makin bertambah banyak; juga sejumlah besar imam menyerahkan diri dan percaya (Kis 6:7)

- Maka sangat besar sukacita dalam kota itu (Kis 8:8)

- Semua penduduk Lida dan Saron melihat Dia, lalu mereka berbalik kepada Tuhan (Kis 9:35)

- Maka Firman makin tersebar dan makin banyak didengar orang (Kis $12: 24)$

- Lalu Firman Tuhan disiarkan di seluruh daerah itu (Kis 13:49) 
- Demikianlah jemaat-jemaat diteguhkan dalam iman dan makin lama makin bertambah besar jumlahnya (Kis 16:5)

- Sehingga semua penduduk Asia mendengar Firman Tuhan, baik orang Yahudi maupun orang Yunani (Kis 19:10)

- Makin tersiarlah Firman Tuhan dan makin berkuasa (Kis 19:20)

- Demikianlah dalam perjalanan keliling dari Yerusalem sampai ke Ilirikum aku telah memberitakan sepenuhnva Injil Kristus (Rm $15: 19)$

Inilah contoh dari pelayanan yang digerakkan oleh strategi dan visi yang jelas, suatu gerakan yang dipimpin dan diawasi oleh Roh Kudus, yang juga disertai dengan penuh ketaatan, ketekunan dan pengorbanan dari lakilaki dan perempuan pemberani. George W. Peters mengatakan sebagai berikut:

Jangan seorang pun menganggap ringan strategi. Strategi bukan mengatur siasat licik. Strategi adalah perencanaan yang bijaksana dan mempunyai maksud serta merupakan prosedur yang teratur untuk mencapai tujuan yang sudah ditetapkan. Strategi sangat penting bagi pertumbuhan Gereja. ${ }^{29}$

\section{PENUTUP: KESIMPULAN DAN REKOMENDASI}

Sebagai suatu fenomena rohani dan teologis, gerakan pertumbuhan Gereja yang dimulai oleh beberapa hamba Tuhan, tidak dapat tidak harus diakui dan diterima sebagai jawaban Tuhan atas kebutuhan rohani Gereja Kristen dan sekaligus sebagai jawaban Tuhan terhadap kemerosotankemerosotan rohani dalam kehadiran dan pelayanan Gereja Tuhan terhadap dunia ini. Karena itu, disarankan supaya Gereja-gereja Tuhan masa kini, perlu masuk dan mengambil bagian yang aktif dan konkrit dalam arus pertumbuhan Gereja ini demi terlaksananya Amanat Agung Tuhan Yesus dalam Matius 28:19-20.

Pengertian atau pun konsep yang benar, proporsional dan konprehensif tentang pertumbuhan Gereja haruslah berdasar dan bertumbuh sesuai dengan pengajaran Alkitab sendiri tentang Teologi Pertumbuhan Gereja. Supaya orang Kristen tahu dan sadar bahwa ide, ilmu Teologi Pertumbuhan Gereja bukanlah ide manusia atau hasil filsafat manusia tetapi

${ }^{29}$ George W. Peters. Theologia Pertumbuhan Gereja (Malang: Gandum Mas, 2002), 278. 
benar-benar adalah ide dan kehendak Allah sendiri bagi Gereja dan dunia ini. Karena itu disarankan supaya pengertian atau pun konsep orang-orang Kristen tentang pertumbuhan Gereja harus terus diperdalam, dipengaruhi dan diperkokoh melalui studi dan pengertian Alkitab.

Kita harus mengerti dan meyakini bahwa upaya Gereja untuk menerapkan ilmu, konsep dan prinsip-prinsip pertumbuhan Gereja yang Alkitabiah perlu mempertimbangkan tantangan, serangan dan hambatanhambatan yang datang dan berbagai segi seperti adanya hambatan karena dangkalnya pengertian sebagian anggota Gereja tentang pentingnya pertumbuhan Gereja. Juga hambatan karena kurangnya pemahaman tentang arti misi Kristus bagi dunia ini. Di samping itu, perlu mempertimbangkan hambatan-hambatan karena bangkitnya agama-agama dunia yang juga sangat misioner dalam gerak dan aksinya, dimana tujuannya juga adalah untuk memenangkan umat manusia bagi agamanya, secara khusus perlu dihitung tantangan yang muncul karena faktor kesalahan sejarah yang dibuat oleh misi atau zending Kristen sendiri dalam beberapa kurun waktu yang lalu. Karena hal ini telah dan terus saja menimbulkan penolakan psikologi dan sosial terhadap hadirnya misi Gereja di berbagai tempat di dunia ini dan di Indonesia khususnya. Namun, yang sangat penting untuk disadari adalah tantangan serius yang datang dan ajaran agama tertentu tentang dosa Syrk. Karena penolakan, kebencian dan serangan pihak agama tertentu terhadap orang-orang Kristen, organisasi Kristen dan teologi Kristen berakar di sini. Makanya disarankan supaya orang-orang Kristen, organisasi dan teologi Kristen harus mampu secara bijaksana dan penuh kasih mensikapi perlakuan orang-orang dari agama tertentu tersebut, tanpa terpancing dalam emosi dan pikiran serta sikap yang merugikan kita sendiri. Jelasnya kita perlu tulus dan cerdik disertai doa yang tak putusputusnya bagi saudara-saudara dari agama tertentu tersebut, agar mereka dapat mengenal Allah yang sejati di dalam Kristus dan bertumhuh di dalam pengetahuan tentang kehenaran (Mat 5:44-45, 10:16; 1Tim 2:3-4).

Kendati pun demikian, bagi kita yang telah mengenal kebenaran tentang pertumbuhan Gereja seperti yang diajarkan Alkitab, tidak ada alasan untuk merasa takut, tawar hati dan menjadi lemah di dalam iman, kehadiran dan pelayanan misi di tengah-tengah tantangan dan hambatanhambatan apa pun, karena Allah sendiri menjamin bahwa Injil Kerajaan Allah yang mengamanatkan pelaksanaan gerak pertumbuhan Gereja akan menyertai, melindungi, melengkapi dan memakai kita agar semua bangsa mendengar Injil sebelum kedatangan-Nya yang kedua kali (Mat 14:14). Mengapa kita harus bersikap dan berpendirian seperti ini? Jawabannya adalah karena terdapat banyak faktor yang menunjang kemungkinan lahir, 
hadir dan berkembangnya Gereja Tuhan di tengah-tengah serigala dunia ini. Karena ltu, disarankan supaya Gereja tetap setia menjalankan perintah Kristus dalam ketergantungan yang terus-menerus kepada Allah pemilik dan pemelihara manusia, supaya kemuliaan akan terus bertambah bagi Dia dalam segala pelayanan kita.

Terdapat empat hal penting tentang prinsip-prinsip pertumbuhan Gereja yang harus kita pertimbangkan dalam upaya menumbuhkan Gereja Tuhan masa kini.

Pertama, prinsip-prinsip (faktor-faktor penunjang pertumbuhan Gereja seperti tertulis dalam makalah ini), tersebut berlaku secara universal, artinya dapat diterapkan pada Gereja-gereja di seluruh dunia, alasannya karena Allah kita adalah Allah untuk seluruh dunia dan semua manusia dan juga karena Gereja yang ada di dalam dunia ini adalah milik Tuhan sendiri yang diperinthkan untuk bertumbuh dalam pengenalan akan Allah (1Tim $2: 3-4 ; 2 \operatorname{Ptr} 3: 8)$.

Kedua, prinsip-prinsip itu dapat ditransfer ke dalam situasi kita masa kini, alasannya adalah karena ketaatan kita kepada perintah Kristus untuk memuridkan semua orang dan segala bangsa menjadi murid Kristus (Mat 28:19-20).

Ketiga, perlu disadari bahwa masing-masing prinsip ini memiliki hubungan yang erat satu sama lain; baik pertumbuhan kualitas, kuantitas maupun organisatoris, karena itu disarankan supaya orang-orang Kristen tidak memandang, dan memperlakukan masing-masing prinsip itu secara terpisah tetapi harus memegang dan menjalankannya secara bersama-sama, saling berkaitan, saling mengisi dan saling mendukung, karena dengan cara demikian pertumbuhan Gereja yang kita dambakan bakal terwujud.

Keempat, tiap-tiap prinsip yang telah dikemukakan merupakan pesan-pesan pokok Alkitab sendiri dengan kata lain, prinsip-prinsip tersebut adalah prinsip Allah sendiri bagi pertumbuhan Gereja-Nya di dunia dalam dunia. Terminologi yang digunakan dalam mengungkapkan prinsip-prinsip tersebut dapat saja tidak sempuma seperti halnya metodologi ilmiah lainnya, tetapi hal itu tidak dapat meniadakan fakta bahwa prinsip tersebut adalah prinsip-prinsip Allah sendiri yang mesti dipegang dan dipatuhi oleh Gereja Tuhan masa kini. Akhirnya, aku (Paulus) menanam, Apolos menyiram, tetapi Allah memberi pertumbuhan (1Kor 3:6). Ini berarti bahwa para petani dapat menanam, menyiram, dan menuiai, tetapi mereka tidak dapat memberi pertumbuhan. Akan telapi mereka tahu bahwa penanaman dan penyiraman yang mereka lakukan benar-benar mempengaruhi tuaian yang diharapkan. 
Akhirnya, kemajuan pertumbuhan Gereja juga sangat ditentukan oleh faktor strategi Tuhan yang dapat kita pelajari dari Alkitab, khususnya kitab Kisah Papa Rasul. Di sana dijelaskan bahwa pertumbuhan Gereja mesti dimulai: (1) di tempat yang dipilih Tuhan, (2) Dilaksanakan dalam waktu Tuhan, (3) Didukung oleh hamba-hamba Tuhan yang dipersiapkan dan dibentuk Tuhan secara khusus, dan (4) Perlu diarahkan dan dibimbing oleh visi misi universal dari Tuhan sendiri. Karena itu, tulisan ini menyarankan agar Gereja-gereja masa kini sungguh-sungguh mencari dan menemukan strategi Tuhan yang khusus untuk tiap-tiap pelayanan misi yang kita kerjakan. 